\title{
Particulate Matter-Based Air Quality Index Estimate for Abuja, Nigeria: Implications for Health
}

\author{
Rogers Bariture Kanee1*, Adewale Adeyemi¹, David Onojiede Edokpa², Precious Nwobidi Ede ${ }^{2}$ \\ ${ }^{1}$ Institute of Geoscience and Space Technology, Rivers State University, Port Harcourt, Nigeria \\ ${ }^{2}$ Department of Geography and Environmental Management, Rivers State University, Port Harcourt, Nigeria \\ Email: *kaneerogers34@gmail.com
}

How to cite this paper: Kanee, R. B., Adeyemi, A., Edokpa, D. O., \& Ede, P. N. (2020). Particulate Matter-Based Air Quality Index Estimate for Abuja, Nigeria: Implications for Health. Journal of Geoscience and Environment Protection, 8, 313-321. https://doi.org/10.4236/gep.2020.85019

Received: April 28, 2020

Accepted: May 26, 2020

Published: May 29, 2020

Copyright $\odot 2020$ by author(s) and Scientific Research Publishing Inc. This work is licensed under the Creative Commons Attribution International License (CC BY 4.0).

http://creativecommons.org/licenses/by/4.0/

\begin{abstract}
In recent years, urban air quality in developing countries such as Nigeria has continued to degenerate and this has constituted a major environmental risk to human health. It has been shown that an increase in ambient particulate matter $\left(\mathrm{PM}_{10}\right)$ load of $10 \mu \mathrm{g} / \mathrm{m}^{3}$ reduces life expectancy by 0.64 years. Air Quality Index (AQI) as demonstrated in this study shows how relatively clean or polluted the boundary layer environment of any location can be. The study was designed to measure the level of suspended particulate matter $\left(\mathrm{PM}_{2.5}\right.$ and $\mathrm{PM}_{10}$ ) for dry and wet seasons, compute the prevalent air quality index of selected locations in Abuja with possible health implications. Suspended particulate matter $\left(\mathrm{PM}_{2.5}\right.$ and $\left.\mathrm{PM}_{10}\right)$ was assessed using handheld aerosol particulate sampler. The US Oak Ridge National AQI was adopted for the eleven (11) locations sampled and monitored. The study results showed that the air quality of the selected areas in Abuja were generally good and healthy. Dry season, assessments, showed $15-95 \mu \mathrm{g} / \mathrm{m}^{3}$ and $12-80 \mu \mathrm{g} / \mathrm{m}^{3}$ for $\mathrm{PM}_{2.5}$ and $\mathrm{PM}_{10}$, respectively. While in wet season, $09-75 \mu \mathrm{g} / \mathrm{m}^{3}$ and $07-65 \mu \mathrm{g} / \mathrm{m}^{3}$ were recorded for $\mathrm{PM}_{2.5}$ and $\mathrm{PM}_{10}$. However at Jebi Central Motor Park, there was light air contamination with AQI of 42 for dry season and 31 for wet season. Other locations had clean air with $\mathrm{AQI} \leq 11$. It is revealed that clean air exists generally during the wet season. Comparing study outcome to other cities in Nigeria, residents of Abuja are likely not to be affected with health hazards of particulate matter pollution. Nonetheless, the high range of $\mathrm{PM}_{2.5}$ and $\mathrm{PM}_{10}$ (fine and coarse particles) ratio evaluated i.e., 1.06 - 1.79 was higher than the WHO recommended standard of $0.5-0.8$. This ratio remains a health concerns for sensitive inhabitants like pregnant women and their foetus as well as infants below age five whose respiratory airways are noted to have high surface areas and absorption capacity for fine particulate matter. Vegetation
\end{abstract}


known to absorb suspended particulate matter should be planted across Abuja metropolitan areas and air quality monitoring stations installed at strategic locations for continuous monitoring and evaluations.

\section{Keywords}

Air Pollution, Particulate Matter, Air Quality Index, Abuja, Health Effects

\section{Introduction}

Atmospheric air pollution is the $4^{\text {th }}$ largest health threat worldwide and the top most environmental risk to human health (WHO, 2016a). Outdoor air pollution contributes about 4.2 million premature deaths annually, with particulate matter noted as the major contributor to air pollution and having the greatest health risk among the air pollutants (WHO, 2020). Globally, nine out of ten people breathe unsafe polluted air; resulting to approximately 7 million deaths annually, as more than $90 \%$ of people live in settlements with unhealthy air quality (WHO, 2016a; WHO, 2018a). An increase in ambient particulate matter $\left(\mathrm{PM}_{10}\right)$ load by $10 \mu \mathrm{g} / \mathrm{m}^{3}$ have been reported to reduce life expectancy by 0.64 years (Ebenstein, Greenstone, \& Zhou, 2017; Edokpa \& Ede, 2019). It is specified that reducing $\mathrm{PM}_{10}$ pollution from 70 to $20\left(\mu \mathrm{g} / \mathrm{m}^{3}\right)$ and annual $\mathrm{PM}_{2.5}$ from levels $35\left(\mu \mathrm{g} / \mathrm{m}^{3}\right)$ commonly noted in developing countries to $10\left(\mu \mathrm{g} / \mathrm{m}^{3}\right)$ can reduce air pollution related death by $15 \%$ (WHO, 2018b).

Urban air quality is noted to be improving in cities of developed countries as against those of low- and middle-income countries such as Abuja in Nigeria (WHO, 2016b). Nigeria is said to have the highest burden of mortalities from poor air quality in Africa and 4th globally (Health Effects Institute, 2018). The country was ranked $150^{\text {th }}$ out of 180 countries for poor environmental performance index on air quality (Yale Center for Environmental law and Policy, 2018). Some cities across Nigeria have been noted to have poor air quality (WHO, 2016c; Yakubu, 2017; Ede \& Edokpa, 2017; Akinfolarin et al., 2017; Edokpa \& Ede, 2019) and with continuous increase in population, urbanization, anthropogenic activities and climate change, concern on the state of air quality in Abuja and other cities across the world such remains important discuss (Petkova et al., 2013). The study assessed suspended particulate matter of size $\mathrm{PM}_{10}$ and $\mathrm{PM}_{2.5}$ during dry and wet seasons, through which prevalent ambient air quality of the selected locations were evaluated and air quality index (AQI) computed.

\section{Materials and Methods}

\subsection{Description and Meteorology of Study Areas}

The surveyed locations are situated in Abuja, the Federal Capital Territory of Nigeria and about 500 meters or 1600 feet above sea level. Inhabitants engage 
mostly in administrative business, with less or insignificant industrial activities. Abuja lies between latitude $8^{\circ} 25^{\prime}$ and $9^{\circ} 25^{\prime}$ north of the equator and longitude $6^{\circ} 45^{\prime}$ and $7^{\circ} 45^{\prime}$ east of Greenwich. It has a land area of 8000 square Kilometers. In the north, it is bounded by Kaduna state, Niger state on the west, Nasarawa state on east and south-east by a south-west by Kogi state respectively (FCDA, 2019). It temperature ranges between $25^{\circ} \mathrm{C}-31^{\circ} \mathrm{C}$ with an equitable climate that is neither too hot nor cold (Balogun, 2001). The study environment experiences two weather conditions annually. These are the rainy season (March through October) and the dry season (October through March). Within these periods, a brief Harmattan period, resulting to dusty haze and intense coldness and dryness due to north east trade wind (FCDA, 2019). Figure 1 show the map of Abuja with surveyed locations.

\subsection{Application of Air Quality Index (AQI)}

Air borne particulate matter $\left(\mathrm{PM}_{2.5}\right.$ and $\left.\mathrm{PM}_{10}\right)$ were assessed using hand held China Way CW-HAT200 Aerosol particulate sampler or counters. The particulate matter was measured by counting and sizing the number of particles in the air. The instrument was held $2 \mathrm{~m}$ above ground level and the air particulates concentration of the sample location determined. The observation was done such that a location was randomly monitored hourly between 6am to 12 noon for dry $\left(11^{\text {th }}-15^{\text {th }}\right.$ February 2019) and wet $\left(17^{\text {th }}-21^{\text {st }}\right.$ June 2019$)$ season respectively. After which daily mean level of the particulate matter was averaged and computed. Table 2 and Table 3 shows the mean concentrations values of particulates measured form the various sampled locations. Criteria pollutants were measured by using a BOSEAN portable gaseous emission analyser to determine

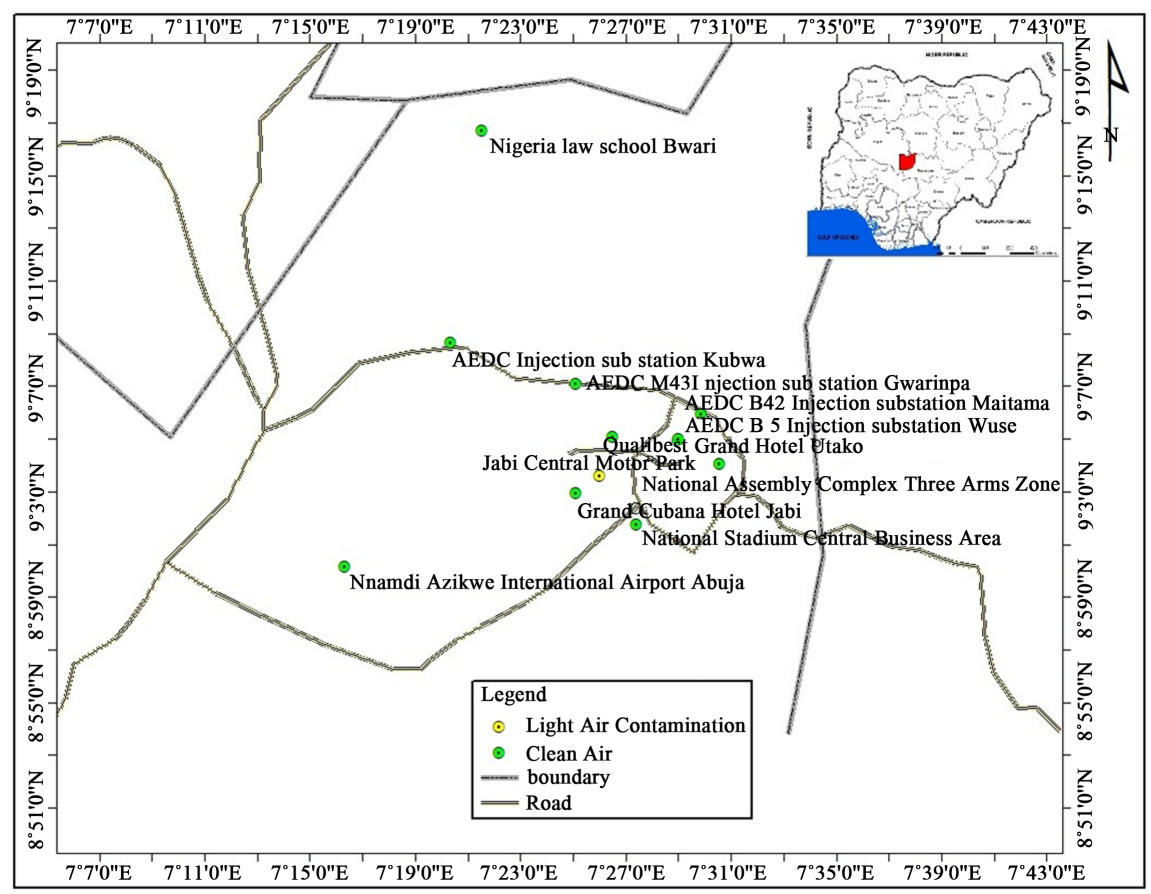

Figure 1. Map of Abuja showing sampled locations. 
Sulphur dioxide $\left(\mathrm{SO}_{2}\right)$, Nitrogen dioxide $\left(\mathrm{NO}_{2}\right)$ and Carbon monoxide (CO). In this method, air was drawn into the analyser gas sensors where it irradiated with pulses of ultra-violet light. Any specified gas of interest in the sample is excited to a higher energy level and upon returning to its original state, light or fluorescence is released. The amount of fluorescence measured was proportional to the gas concentration.

The coordinates of the location was obtained with a GARMIN OREGON 550t Serial number IMY059637 GPS Receiver instrument configured in the Nigerian Minna datum with the geodetic co-ordinates of the points already imputed into the system. In the navigation mode, this equipment provides a compass of the target position, elevation above sea level and the UTM Coordinates of this target position. The meteorological parameters was measured with a 5 in 1 (Ambient Temperature, wind speed, wind direction, relative humidity, atmospheric pressure) SPER Scientific 850,022 Serial number AE. 64,638. The monitor was held at arm's length above the head and approximately $2.5 \mathrm{~m}$ above the ground and no closer than $3 \mathrm{~m}$ to any reflecting surface.

The US Oak Ridge National Laboratory (ORNL) AQI was utilised for analysis of air quality index. The ORNL AQI has advantage for the relative ranking of overall air quality status at different locations of the study area with different air pollutants parameter. The AQI values were categorised as clean air, light air contamination, moderate air contamination, heavy air contamination, severe air contamination (Edokpa \& Ede, 2019). The AQI for each period in the study area was estimated with the help of a mathematical equation developed by the Oak Ridge National Laboratory (ORNL) and given as:

$$
\mathrm{AQI}=\left[5.7 \sum I_{i}\right] 1.37
$$

where, $I_{i}=X / X_{s} X=$ observed pollutants concentrations for $\mathrm{PM}_{10}$ and $\mathrm{PM}_{2.5} ; X_{s}=$ pollutant standard at National hourly values of $70 \mu \mathrm{g} / \mathrm{m}^{3}$ and $30 \mu \mathrm{g} / \mathrm{m}^{3}$ for $\mathrm{PM}_{10}$ and $\mathrm{PM}_{2.5}$, respectively; $I=$ pollutant, while 5.7 and 1.37 are constants. The index scale is demarcated from 0 to 100 and further divided into 5 sub categories of air quality groups. This index rating is shown in Table 1.

\section{Results and Discussion}

\subsection{Data Presentation}

Table 2 and Table 3 show the outcome of field measurements conducted during

Table 1. Air quality index.

\begin{tabular}{cc}
\hline Index Value & Description \\
\hline $00-25$ & Clean air \\
$26-50$ & Light air contamination \\
$51-75$ & Moderate air contamination \\
$76-100$ & Heavy air contamination \\
AQI $>100$ & Severe air contamination \\
\hline
\end{tabular}


Table 2. Dry season sampling: $11^{\text {th }}-15^{\text {th }}$ February 2019.

\begin{tabular}{|c|c|c|c|c|c|c|c|c|c|}
\hline Name of Location & Location of & Coordinates & $\begin{array}{c}\mathrm{PM}_{2.5} \\
\left(\mu \mathrm{g} / \mathrm{m}^{3}\right)\end{array}$ & $\begin{array}{c}\mathrm{PM}_{10} \\
\left(\mu \mathrm{g} / \mathrm{m}^{3}\right)\end{array}$ & $\begin{array}{l}\text { Rel. Hum. } \\
\text { (\%) }\end{array}$ & $\begin{array}{l}\text { Temp. } \\
\left({ }^{\circ} \mathrm{C}\right)\end{array}$ & $\begin{array}{c}\mathrm{SO}_{\mathrm{x}} \\
(\mathrm{ppm})\end{array}$ & $\begin{array}{l}\mathrm{NO}_{\mathrm{x}} \\
(\mathrm{ppm})\end{array}$ & $\begin{array}{c}\mathrm{CO} \\
(\mathrm{ppm})\end{array}$ \\
\hline $\begin{array}{l}\text { AEDC M43 Injection } \\
\text { Substation (Gwarinpa) }\end{array}$ & N09 $07^{\prime} 03.4^{\prime \prime}$ & $\mathrm{E} 007^{\circ} 25^{\prime} 08.6^{\prime \prime}$ & 034 & 023 & 52 & 32 & 0.01 & 0.02 & 3 \\
\hline $\begin{array}{l}\text { AEDC B42 Injection } \\
\text { Substation (Maitama) }\end{array}$ & N09 $05^{\prime} 54.8^{\prime \prime}$ & $\mathrm{E} 007^{\circ} 29^{\prime} 53.1^{\prime \prime}$ & 021 & 018 & 50 & 33 & 0.01 & 0.01 & 2 \\
\hline $\begin{array}{c}\text { AEDC Injection } \\
\text { Substation (Kubwa) }\end{array}$ & N0908'39.2" & $\mathrm{E} 007^{\circ} 20^{\prime} 22.2^{\prime \prime}$ & 020 & 017 & 48 & 34 & 0.01 & 0.08 & 10 \\
\hline $\begin{array}{l}\text { AEDC B5 Injection } \\
\text { Substation (Wuse) }\end{array}$ & N09 $04^{\prime} 34.3^{\prime \prime}$ & $\mathrm{E} 007^{\circ} 29^{\prime} 04.6^{\prime \prime}$ & 018 & 014 & 46 & 32 & 0.01 & 0.02 & 3 \\
\hline $\begin{array}{l}\text { Qualibest Grand } \\
\text { Hotel (Utako) }\end{array}$ & N09 $04^{\prime} 28.37^{\prime \prime}$ & $\mathrm{E} 007^{\circ} 27^{\prime} 04.33^{\prime \prime}$ & 021 & 017 & 47 & 30 & 0.01 & 0.01 & 2 \\
\hline Jabi Central Motor Park & N0903'53.69" & $\mathrm{E} 007^{\circ} 26^{\prime} 02.20^{\prime \prime}$ & 095 & 080 & 44 & 33 & 0.04 & 0.10 & 16 \\
\hline $\begin{array}{l}\text { National Assembly } \\
\text { Complex } \\
\text { (Three Arms Zone) }\end{array}$ & N09 $03^{\prime} 58.36^{\prime \prime}$ & E007³0'29.86" & 015 & 012 & 50 & 30 & $<0.01$ & $<0.01$ & 1 \\
\hline $\begin{array}{l}\text { Grand Cubana Hotel } \\
\text { (Jabi) }\end{array}$ & N09 $03^{\prime} 45.23^{\prime \prime}$ & $\mathrm{E} 007^{\circ} 25^{\prime} 22.15^{\prime \prime}$ & 029 & 024 & 45 & 34 & 0.10 & 0.20 & 7 \\
\hline $\begin{array}{c}\text { Nnamdi Azikwe } \\
\text { International Airport } \\
\text { (Abuja) }\end{array}$ & N09 $00^{\prime} 12.96^{\prime \prime}$ & $\mathrm{E} 007^{\circ} 16^{\prime} 47.46^{\prime \prime}$ & 031 & 025 & 40 & 30 & 0.02 & 0.03 & 2 \\
\hline $\begin{array}{c}\text { National Stadium } \\
\text { (Central Business Area) }\end{array}$ & N09 $02^{\prime} 17.57^{\prime \prime}$ & $\mathrm{E} 007^{\circ} 27^{\prime} 13.77^{\prime \prime}$ & 039 & 032 & 46 & 33 & 0.01 & 0.04 & 3 \\
\hline $\begin{array}{l}\text { Nigerian Law School } \\
\text { (Bwari) }\end{array}$ & N09 ${ }^{\circ} 16^{\prime} 43.69^{\prime \prime}$ & $\mathrm{E} 007^{\circ} 21^{\prime} 33.15^{\prime \prime}$ & 038 & 034 & 48 & 31 & 0.01 & 0.04 & 2 \\
\hline \multicolumn{3}{|c|}{$\begin{array}{c}\text { World Health Organization (WHO) } \\
\text { Air Quality Standard } \\
\text { (WHO, 2018b) }\end{array}$} & $\begin{array}{l}25 \mu \mathrm{g} / \mathrm{m}^{3} \\
(24 \text { hours } \\
\text { mean); } \\
10 \mu \mathrm{g} / \mathrm{m}^{3} \\
\text { (annual } \\
\text { mean) }\end{array}$ & $\begin{array}{c}50 \mu \mathrm{g} / \mathrm{m}^{3} \\
(24 \text { hours } \\
\text { mean); } \\
20 \mu \mathrm{g} / \mathrm{m}^{3} \\
\text { (annual } \\
\text { mean }\end{array}$ & - & - & $\begin{array}{c}0.007 \text { ppm } \\
\text { (24 hours } \\
\text { mean); } \\
0.5 \text { ppm } \\
\text { (10 minute } \\
\text { mean) }\end{array}$ & $\begin{array}{l}0.05 \text { ppm } \\
\text { (24 hours } \\
\text { mean); } \\
0.07 \text { ppm } \\
\text { (1 hour } \\
\text { mean) }\end{array}$ & $\begin{array}{l}8.11 \mathrm{ppm} \\
\text { ( } 8 \text { hours } \\
\text { mean); } \\
24.3 \mathrm{ppm} \\
\text { ( } 1 \text { hour } \\
\text { mean) }\end{array}$ \\
\hline
\end{tabular}

Table 3. Wet season sampling: $17^{\text {th }}-21^{\text {st }}$ June 2019 .

\begin{tabular}{|c|c|c|c|c|c|c|c|c|c|}
\hline Name of Location & \multicolumn{2}{|c|}{ Location of Coordinates } & $\begin{array}{c}\mathrm{PM}_{2.5} \\
\left(\mu \mathrm{g} / \mathrm{m}^{3}\right)\end{array}$ & $\begin{array}{c}\mathrm{PM}_{10} \\
\left(\mu \mathrm{g} / \mathrm{m}^{3}\right)\end{array}$ & $\begin{array}{l}\text { Rel. Hum. } \\
\text { (\%) }\end{array}$ & $\begin{array}{l}\text { Temp. } \\
\left({ }^{\circ} \mathrm{C}\right)\end{array}$ & $\begin{array}{c}\mathrm{SO}_{\mathrm{x}} \\
(\mathrm{ppm})\end{array}$ & $\begin{array}{c}\mathrm{NO}_{\mathrm{x}} \\
(\mathrm{ppm})\end{array}$ & $\begin{array}{c}\mathrm{CO} \\
(\mathrm{ppm})\end{array}$ \\
\hline $\begin{array}{l}\text { AEDC M43 Injection } \\
\text { Substation (Gwarinpa) }\end{array}$ & N09 $07^{\prime} 03.4^{\prime \prime}$ & $\mathrm{E} 007^{\circ} 25^{\prime} 08.6^{\prime \prime}$ & 025 & 014 & 69 & 28 & 0.01 & 0.02 & 2 \\
\hline $\begin{array}{l}\text { AEDC B42 Injection } \\
\text { Substation (Maitama) }\end{array}$ & N09 $05^{\prime} 54.8^{\prime \prime}$ & $\mathrm{E} 007^{\circ} 29^{\prime} 53.1^{\prime \prime}$ & 012 & 009 & 68 & 29 & $<0.01$ & $<0.01$ & 2 \\
\hline $\begin{array}{c}\text { AEDC Injection } \\
\text { Substation (Kubwa) }\end{array}$ & N0908'39.2" & $\mathrm{E} 007^{\circ} 20^{\prime} 22.2^{\prime \prime}$ & 015 & 012 & 70 & 30 & 0.01 & 0.08 & 8 \\
\hline $\begin{array}{l}\text { AEDC B5 Injection } \\
\text { Substation (Wuse) }\end{array}$ & N09 $04^{\prime} 34.3^{\prime \prime}$ & $\mathrm{E} 007^{\circ} 29^{\prime} 04.6^{\prime \prime}$ & 012 & 009 & 70 & 29 & $<0.01$ & $<0.01$ & 3 \\
\hline $\begin{array}{l}\text { Qualibest Grand } \\
\text { Hotel (Utako) }\end{array}$ & N0904'28.37" & $\mathrm{E} 007^{\circ} 27^{\prime} 04.33^{\prime \prime}$ & 013 & 009 & 73 & 28 & $<0.01$ & $<0.01$ & 0 \\
\hline
\end{tabular}




\section{Continued}

\begin{tabular}{|c|c|c|c|c|c|c|c|c|c|}
\hline Jabi Central Motor Park & N09 $03^{\prime} 53.69^{\prime \prime}$ & $\mathrm{E} 007^{\circ} 26^{\prime} 02.20^{\prime \prime}$ & 075 & 065 & 72 & 31 & 0.02 & 0.09 & 14 \\
\hline $\begin{array}{c}\text { National Assembly } \\
\text { Complex } \\
\text { (Three Arms Zone) }\end{array}$ & N09 $03^{\prime} 58.36^{\prime \prime}$ & $\mathrm{E} 007^{\circ} 30^{\prime} 29.86^{\prime \prime}$ & 009 & 007 & 72 & 29 & $<0.01$ & $<0.01$ & 0 \\
\hline $\begin{array}{c}\text { Grand Cubana } \\
\text { Hotel (Jabi) }\end{array}$ & N09 $03^{\prime} 45.23^{\prime \prime}$ & $\mathrm{E} 007^{\circ} 25^{\prime} 22.15^{\prime \prime}$ & 018 & 014 & 70 & 29 & 0.10 & 0.20 & 5 \\
\hline $\begin{array}{c}\text { Nnamdi Azikwe } \\
\text { International } \\
\text { Airport (Abuja) }\end{array}$ & N09 $00^{\prime} 12.96^{\prime \prime}$ & $\mathrm{E} 007^{\circ} 16^{\prime} 47.46^{\prime \prime}$ & 023 & 019 & 68 & 30 & $<0.01$ & $<0.01$ & 2 \\
\hline $\begin{array}{c}\text { National Stadium } \\
\text { (Central Business Area) }\end{array}$ & N09 $02^{\prime} 17.57^{\prime \prime}$ & $\mathrm{E} 007^{\circ} 27^{\prime} 13.77^{\prime \prime}$ & 030 & 025 & 65 & 29 & 0.01 & 0.04 & 3 \\
\hline $\begin{array}{c}\text { Nigerian Law } \\
\text { School (Bwari) }\end{array}$ & N09 ${ }^{\circ} 16^{\prime} 43.69^{\prime \prime}$ & $\mathrm{E} 007^{\circ} 21^{\prime} 33.15^{\prime \prime}$ & 035 & 033 & 68 & 31 & $<0.01$ & $<0.01$ & 1 \\
\hline 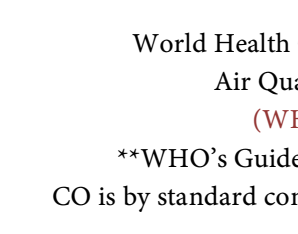 & $\begin{array}{l}\text { Organization (W } \\
\text { lity Standards } \\
\mathrm{O}, 2018 \mathrm{~b}) \\
\text { lines for } \mathrm{NO}_{\mathrm{x}}, \mathrm{SC} \\
\text { version from } \mu \mathrm{g}\end{array}$ & $\begin{array}{l}\mathrm{HO}) \\
\mathrm{m}^{3} \text { to } \mathrm{ppm} \text {. }\end{array}$ & $\begin{array}{c}25 \mu \mathrm{g} / \mathrm{m}^{3} \\
(24 \text { hours } \\
\text { mean); } \\
10 \mu \mathrm{g} / \mathrm{m}^{3} \\
\text { (annual } \\
\text { mean) }\end{array}$ & $\begin{array}{l}50 \mathrm{~g} / \mathrm{m}^{3} \\
(24 \text { hours } \\
\text { mean); } \\
20 \mu \mathrm{g} / \mathrm{m}^{3} \\
\text { (annual } \\
\text { mean) }\end{array}$ & - & - & $\begin{array}{c}0.01 \mathrm{ppm} \\
\text { (24 hours } \\
\text { mean); } \\
0.19 \mathrm{ppm} \\
\text { (10 minute } \\
\text { mean) }\end{array}$ & $\begin{array}{l}0.08 \mathrm{ppm} \\
\text { (24 hours } \\
\text { mean); } \\
0.11 \mathrm{ppm} \\
\text { ( } 1 \text { hour } \\
\text { mean) }\end{array}$ & $\begin{array}{c}8.73 \mathrm{ppm} \\
\text { (8 hours } \\
\text { mean); } \\
26.2 \mathrm{ppm} \\
\text { (1 hour } \\
\text { mean) }\end{array}$ \\
\hline
\end{tabular}

the study survey at the various locations. The recorded air quality indicators are used to analyse the AQI for the locations and shown in Table 4.

\subsection{Analysis of Results}

Generally, the study result showed that the air quality of Abuja remains good and very different from what is obtained from other Nigerian cities such as Port Harcourt (Taiwo et al., 2015; Ede \& Edokpa, 2015; WHO, 2016; Quartz Africa, 2017). The status of air quality in the area shows that the enforced urban plan setting is viable for air quality management. The National Assembly Complexthree Arms Zone had the best state of air, this might not be far from less population density, better state of vehicles with little or no emissions and presence of tree in the area. On the contrary, Jabi Central Motor Park location had the worst state of air (AQI of 42 for dry season and 31 for wet season) when compared to other locations in the study (shown in Table 4). This can be explained from the population density of the area, the industrial nature of the area, the volume of cars and it exhaust fumes and possibly wind direction. This supports the studies that found population density and industrial ecology as implicative factors of air population (Weli, 2014). In terms of seasonal variations, the result shows that Air quality of wet season was cleaner than that of dry season. In as much the study found Abuja to have clean air, the study results also negate reports of coarse particles ( $\mathrm{PM}_{10}$ and above) in the air of Nigerian cities (Offor et al., 2016) as the computed $\mathrm{PM}_{2.5}$ and $\mathrm{PM}_{10}$ ratios indicated higher values of fine particles (1.06 1.79) above WHO standard of 0.5 - 0.8. This is worrisome, as smaller particles are known to easily enter into the lower region of the lungs (Miller et al., 2018). The health implications of smaller particulate size such as $\mathrm{PM}_{2.5}$ have been established (Mark et al., 2018). 
Table 4. Air quality index.

\begin{tabular}{|c|c|c|c|c|}
\hline NAME OF LOCATION & $\begin{array}{c}\text { AQI } \\
\text { (Dry season) }\end{array}$ & $\begin{array}{l}\text { Implication } \\
\text { (Dry season) }\end{array}$ & $\begin{array}{c}\text { AQI } \\
\text { (Wet Season) }\end{array}$ & $\begin{array}{l}\text { Implication } \\
\text { (Wet season) }\end{array}$ \\
\hline $\begin{array}{l}\text { AEDC M43 Injection } \\
\text { Substation (Gwarinpa) }\end{array}$ & 9 & Clean air & 6 & Clean air \\
\hline $\begin{array}{l}\text { AEDC B42 Injection } \\
\text { Substation (Maitama) }\end{array}$ & 5 & Clean air & 3 & Clean air \\
\hline $\begin{array}{c}\text { AEDC Injection } \\
\text { Substation (Kubwa) }\end{array}$ & 5 & Clean air & 4 & Clean air \\
\hline $\begin{array}{l}\text { AEDC B5 Injection } \\
\text { Substation (Wuse) }\end{array}$ & 5 & Clean air & 3 & Clean air \\
\hline Qualibest Grand Hotel (Utako) & 5 & Clean air & 3 & Clean air \\
\hline Jabi Central Motor Park & 42 & $\begin{array}{c}\text { Light air } \\
\text { contamination }\end{array}$ & 31 & $\begin{array}{c}\text { Light air } \\
\text { contamination }\end{array}$ \\
\hline $\begin{array}{l}\text { National Assembly Complex } \\
\text { (Three Arms Zone) }\end{array}$ & 4 & Clean air & 2 & Clean air \\
\hline Grand Cubana Hotel (Jabi) & 8 & Clean air & 5 & Clean air \\
\hline $\begin{array}{c}\text { Nnamdi Azikwe International } \\
\text { Airport (Abuja) }\end{array}$ & 9 & Clean air & 6 & Clean air \\
\hline $\begin{array}{c}\text { National Stadium } \\
\text { (Central Business Area) }\end{array}$ & 12 & Clean air & 8 & Clean air \\
\hline Nigerian Law School (Bwari) & 12 & Clean air & 11 & Clean air \\
\hline
\end{tabular}

\section{Conclusion}

Although seasonal variation was noted, with wet season having the better AQI, the study found AQI of Abuja, the Federal Capital of Nigeria, to be generally clean. Of all the study sampled locations, Jabi Central Motor Park was the only location with light contaminated air (AQI of 31) while the rest locations recorded less than AQI of 25 ( $\leq 11$ AQI). The population density, vehicular emissions rates and industrial nature of Jabi Central Motor Park were likely factors responsible for it moderate contamination. The study showed that residents of Abuja are likely to be at low risk of air pollution morbidities compared to other cities in Nigeria. But the $\mathrm{PM}_{2.5}$ and $\mathrm{PM}_{10}$ ratio evaluation remain a concern, especially for pregnant women and their foetus, infants ( 0 - 5 years) and persons with existing respiratory dysfunctions. Air Quality Monitoring Stations should be installed at strategic locations for continuous air quality trend monitoring, especially as the city get more populated and urbanized. Systematic collaboration should be instituted between environmental and health agencies for data sharing and proactive public health interventions. Regular monitoring will ensure that vulnerable groups are protected and expose to ambient air with minimal air pollution risk. Also, special trees known to absorb fine particulates should be planted across the city.

\section{Conflicts of Interest}

The authors declare no conflicts of interest regarding the publication of this paper. 


\section{References}

Akinfolarin, O.M., Boisa, N., \& Obunwo, C.C. (2017). Assessment of Particulate Mat ter-Based Air Quality Index in Port Harcourt, Nigeria. Journal of Environmental Analytical Chemistry, 4, 1-4. https://doi.org/10.4172/2380-2391

Balogun, O. (2001). The Federal Capital of Nigeria: A Geography of Its Development. Ibadan: Ibadan University Press, University of Ibadan.

Ebenstein, A., Fan, M., Greenstone, M., He, G., \& Zhou, M. (2017). New Evidence in the Impact of Sustained Exposure to Air Pollution on Life Expectancy from China's Haui River Policy. PNAS, 114, 10384-10389. https://doi.org/10.1073/pnas.1616784114

Ede, P. N., \& Edokpa, O. D. (2015). Regional Air Quality of the Nigeria's Niger Delta. Open Journal of Air Pollution, 4, 7-15.

Ede, P. N., \& Edokpa, O. D. (2017). Satellite Determination of Particulate Load over Port Harcourt during Black Soot Incidents. Journal of Atmospheric Pollution, 5, 55-61.

Edokpa, D. O., \& Ede, P. N. (2019). Preliminary Air Quality Index Estimates of Particulates Concentration in Port Harcourt during Soot Incidents. International Journal of Innovative Studies in Sciences and Engineering Technology, 5, 25-29.

FCDA (Federal Capital Development Authority) (2019). The Geography of Abuja. https://www.fcda.gov.ng/index.php/about-fcda/the-geography-of-abuja

Health Effects Institute (2018). State of Global Air 2018: "Over 7 billion people face un safe air. Special Report”. Boston, MA: Health Effects Institute.

Mark, B., Scor, L. I., \& Life, G. (2018). Health Impacts of Air Pollution.

Miller, L., \& Xu, X. (2018). Ambient PM2.5 Human Health Effects-findings in China and Research Directions. Atmosphere, 9, 424. https://doi.org/10.3390/atmos9110424

Offor, I. F., Adie, G. U., \& Ana, G. R. (2016). Review of Particulate Matter and Elemental Composition of Aerosols at Selected Location in Nigeria from 1985-2015. Journal of Health and Pollution, 6, 1-18.

https://www.ncbi.nlm.nih.gov/pmc/articles/PMC6236551/pdf/i2156-9614-10-1.pdf https://doi.org/10.5696/2156-9614-6-10.1

Petkova, E. P., Jack, D. W., Volavka-Close, N. H., \& Kinney, P. L. (2013). Particulate Matter Pollution in African Cities. Air Quality, Atmosphere \& Health, 6, 603-614. https://doi.org/10.1007/s11869-013-0199-6

Quartz Africa (2017). Four of the World's Worst-Ranked Cities for Air Quality Air in Nigeria.

https://qz.com/686071/four-of-the-worst-ranked-countries-for-air-quality-are-in-nigeria/

Rivers State Ministry of Environment (2019). A Study of Airborne Particulate "Black Soot" in Port Harcourt and Its Environs. Port Harcourt: Government of Rivers State.

Taiwo, A. M. Arowolo, T. A., Abdullahi, K. L., \& Taiwo, O. T. (2015). Particulate Matter Pollution in Nigeria: A Review. The 14th International Conference on Environmental Science and Technology, Rhodes, 3-5 September 2015.

Weli, V. E. (2014). Atmospheric Concentration of Particulate Pollutants and its Implication for Respiratory Health Hazard Management in Port Harcourt Metropolis, Nigeria. Civil and Environmental Research, 6, 11-17.

WHO (World Health Organization) (2016a). Ambient Air Pollution: A Global Assessment of Exposure and Burden of Disease.

WHO (World Health Organization) (2016b). WHO Global Urban Ambient Air Pollution Data Base (Update 2016).

WHO (World Health Organization) (2016c). WHO's Urban Ambient Air Pollution 
Database-Update 2016.

https://www.who.int/phe/health_topics/outdoorair/databases/AAP_database_summary _results_2016_v02.pdf

WHO (World Health Organization) (2018a). 9 out of 10 People Worldwide Breathe Polluted Air, but More Countries Are Taking Action.

https://www.who.int/news-room/details/02-05-2018-out-of-10-people-worldwide-bre athe- polluted-air-but-more-countries-are-taking-action

WHO (World Health Organization) (2018b). Ambient (Outdoor) Air Pollution. WHO Fact Sheet on Ambient Air Quality Guidelines.

WHO (World Health Organization) (2020). Ambient Air Pollution: Health Impacts. https://www.who.int/airpollution/ambient/health-impacts/en/

Yakubu, O. H. (2017). Particulate (Soot) in Port Harcourt Rivers State, Nigeria-Double Air Pollution Burden. Understanding and Tackling Potential Environmental Public Health Impacts. Environments, 5, 1-22. https://doi.org/10.3390/environments5010002

Yale Center for Environmental Law \& Policy (2018). 2018 Environmental Performance Index. 